\title{
Pengaruh Paramater Pengelasan In-Service Pada Proses Hot Tap Pipa Penyalur Gas Alam Bertekanan
}

\author{
M. H. Wahyudi* dan M. W. Wildan \\ Departemen Teknik Mesin dan Industri, Fakultas Teknik, Universitas Gadjah Mada. \\ Jl. Grafika No.2, Kompleks UGM, Yogyakarta 55281, Indonesia, \\ Telp. (0274) 521673 \\ e-mail: *maulana.hendra.w@mail.ugm.ac.id
}

\begin{abstract}
Abstrak
Pada proses pengelasan dalam kondisi pipa dengan aliran dan tekanan didalamnya (in-service welding) ada dua risiko yang perlu dipertimbangkan yaitu burnthrough di mana busur pengelasan menyebabkan dinding pipa terbuka sehingga isi pipa dapat keluar dan yang berikutnya adalah retak hidrogen yaitu terjadinya retak pada daerah Heat Affected Zone (HAZ) yang timbul sebagai akibat laju pendinginan cepat yang dihasilkan oleh fluida di dalam pipa. Untuk mencegah hal tersebut terjadi maka perlu dilakukan pengembangan penentuan parameter pengelasan yang bertujuan untuk meminimalkan pembentukan struktur mikro yang rentan terhadap retak dan menghindari terjadinya burnthrough. Tujuan dari penelitian ini adalah untuk menentukan parameter pengelasan yang aman untuk aplikasi pengelasan in-service selama proses hot tapping pipa gas alam di PT. XYZ yang berlokasi di Kalimantan Timur tanpa melakukan penghentian fasilitas dalam beroperasi. Penelitian ini terdiri dari dua langka utama yaitu simulasi komputer dan eksperimen. Langkah pertama parameter nilai masukan panas pengelasan (heat input) dihitung menggunakan perangkat lunak komersial PRCI untuk memprediksi kekerasan di daerah HAZ agar memiliki nilai $\leq 350 \mathrm{HV}$ dan prediksi suhu permukaan bagian dalam pipa resiko dimana nilai yang dikategorikan aman adalah $\leq 982^{\circ} \mathrm{C}$. Langkah selanjutnya adalah melakukan proses eksperimen menggunakan material API 5L Gr. X52 dengan ukuran diameter 12", tebal $6,25 \mathrm{~mm}$, dan kecepatan aliran linier air didalam pipa $0,07 \mathrm{~m} / \mathrm{s}$. Proses pengelasan menggunakan metode GTAW dan SMAW, dengan elektroda masing - masing ER70S-6 diameter 2,4 mm dan E7018 H4R dengan diameter 3,2 mm. Ada tiga kelompok parameter pengelasan yang disimulasikan yaitu beat input rendah, heat input tinggi, dan beat input temper bead dengan perlakukan preheat. Hasil yang dipilih adalah metode dengan nilai hasil kekerasan terendah yaitu heat input temper bead $(1,38 \mathrm{~kJ} / \mathrm{mm})$ dimana didapatkan nilai kekerasan HAZ 230,8 HV dan temperature didalam pipa sebesar $624{ }^{\circ} \mathrm{C}$. Laju pendinginan air pada saat eksperimen berdasarkan kemampuan pompa sebesar $0,07 \mathrm{~m} / \mathrm{s}$ dapat mewakili laju pendinginan gas alam pada kondisi aktual. Pada saat eksperimen didapat nilai kekerasan kritikal pada HAZ yang sedikit lebih tinggi dari prediksi yaitu $235 \mathrm{HV}$, tetapi masih jauh lebih rendah dari batas kritikal. Dari hasil simulasi dan eksperimen disimpulkan bahwa metode temper bead, penggunaan metode GTAW dan perlakuan preheat dapat menghasilkan parameter pengelasan yang aman untuk melakukan pengelasan inservice pada proses hot tapping pipa gas bertekanan.
\end{abstract}

Kata kunci : Pengelasan In-service, API 5L X52, Kekerasan, Daerah terpengaruh panas (HAZ), temper bead pengelasan. 
M. H. Wahyudi dan M. W. Wildan/ Journal of Mechanical Design and Testing 3(1), (2021), 57-66

\begin{abstract}
During welding on pipe with live fluid and pressure inside (in-service welding) two risks need to be considered. The first is the risk of burnthrough, where the welding arc causes the pipe wall to be penetrated allowing the contents to escape. The second is the risk of bydrogen cracking that arises from the fast cooling rates of pipe wall from fluid cooling. To prevent these risks a safe welding parameters shall be established to minimize the formation of crack susceptible microstructures and avoiding burnthrough. The objective of this research is to determine safe welding parameter for in-service welding application during natural gas pipeline hot tapping process at PT. XYZ located in East Kalimantan. This research consists of two main steps, first step, welding parameter like heat input for bead was approximately calculated by commercial software PRCI program to predict critical HAZ hardness to have value less than $350 \mathrm{HV}$ and the inside surface temperature of less than $1800^{\circ} \mathrm{F}\left(982^{\circ} \mathrm{C}\right)$. Next step is to perform welding experiment using material of API 5L Gr. X52 pipe steel with diameter 12", wall thickness of $6.25 \mathrm{~mm}$ and linear flow velocity of $0,07 \mathrm{~m} / \mathrm{s}$. GTAW and $S M A W$ welding process were used, with consumable 2,4 mm diameter ER70S-6 and 3,2 mm diameter low bydrogen E7018 H4R respectively. There were three welding parameters groups named low heat input, high heat input and temper bead heat input were calculated. As the results temper bead heat input was selected since with the same heat input of $1,38 \mathrm{~kJ} / \mathrm{mm}$ the $\mathrm{HAZ}$ hardness of 230,8 HV and temperature inside the pipe of $624{ }^{\circ} \mathrm{C}$ were predicted. Water cooling rate during experiment was following pump capacity $0,07 \mathrm{~m} / \mathrm{s}$ and can be use to represent actual gas flow. During experiment slightly higher HAZ hardness of $235 \mathrm{HV}$ at the run pipe was attained in the actual welding, this still far below crititcal hardness limit. The use of temper bead technique, GTAW welding process and preheat application can produce safe welding paramater for in-service welding during hot tapping process in gas pipeline. This study found, ASME-B31G level 1 conservatism require correction factors related to its corrosion width.
\end{abstract}

Keywords : In-service welding, API 5L X52, Hardness, Heat Affected Zone (HAZ), temper bead welding.

\title{
1. PENDAHULUAN
}

Hot tapping adalah teknik pemasangan dan penyambungan pipa baru ke pipa lama yang sedang aktif beroperasi dengan cara mengebor bagian dari pipa lama dimana pipa baru tersebut akan dipasangkan. Di dalam suatu fasilitas, selalu ada kemungkinan penambahan cabang perpipaan, perubahan jalur perpipaan, pemasangan katup baru, pemasangan alat-alat instrumentasi dimana diharapkan semuanya ini dilakukan tanpa mengganggu operasi yang sedang berjalan. Pada dasarnya hot tapping tidak diinginkan mengingat resikonya sangat tinggi terutama apabila fluida di dalam pipa mempunyai sifat mudah terbakar, bagaimanapun proses ini memiliki nilai ekonomis yang signifikan karena dapat menghindari biaya yang timbul jika terjadi penghentian operasi. Karena hal tersebut perlu dilakukan kajian yang lebih mendalam mengenai resiko atau bahaya apa yang bisa terjadi bila harus dilakukan pekerjaan tersebut dan bagaimana cara untuk memitigasinya.

Suatu pipa penyalur dikatakan dalam kondisi in-service atau aktif jika didalamnya berisi fluida operasi (seperti produk minyak bumi atau gas alam) yang mungkin bertekanan dan dengan atau tanpa ada aliran. Ada dua masalah utama dalam pengelasan in-service yaitu burnthrough dan retak hidrogen. Pengelasan in-service harus memiliki keseimbangan antara keselamatan terhadap personel/operasi di satu sisi dan pencegahan timbulnya karakterisitik material yang tidak diinginkan di sisi lain. Heat input pengelasan perlu dibatasi untuk meminimalkan risiko terjadinya burnthrough, namun rendahnya nilai heat input bisa tidak mencukupi untuk mengatasi kemampuan 
pendinginan oleh fluida di dalam pipa dalam menghilangkan panas pada lasan, sehingga terjadi laju pendinginan berlebihan yang meningkatkan resiko terjadinya retak hidrogen.

Beberapa peneliti seperti Bruce (2002) menyatakan bahwa kekerasan pada daerah terpengaruh panas (HAZ) adalah indikator adanya mikrostruktur yang rentan terhadap retak hydrogen, nilai kritis untuk terjaidnya retak adalah jika kekerasan daerah lasan $350 \mathrm{HV}$. Dalam penelitiannya Huang dkk. (2017) menyatakan bahwa laju aliran dan tekanan gas dalam pipa secara signifikan mempengaruhi koefisien perpindahan panas pada pipa yang mengalami panas akibat proses pengelasan. Sementara itu mengenai kandungan hidrogen Farzadi (2015) menyimpulkan bahwa untuk pengelasan in-service, kandungan hidrogen dalam elektroda dijaga pada tingkat terendah dengan penggunaan elektroda dasar rendah hidrogen (tipe H4R). Didalam penelitiannya Srisutraporn dkk. (2018) menjelaskan bahwa metode temper bead pengelasan secara signifikan bisa menurunkan nilai maksimum kekerasan di area HAZ pada pengelasan in-service. Studi ini bertujuan untuk menentukan parameter pengelasan yang diperlukan untuk melakukan proses pengelasan in-service pipa penyalur fluida gas alam berbahan pipa API 5L Grade X52 dengan aman dan tanpa melakukan perubahan parameter operasi pipa.

\section{METODE PENELITIAN}

\subsection{Material Eksperimen}

Penelitian dimulai dengan mengumpulkan informasi mengenai parameter operasi pipa penyalur gas alam yang menjadi obyek penelitian seperti yang ditampilkan pada Tabel 1. dan menjadi acuan dalam penentuan parameter pengelasan. Eksperimen dilakukan menggunakan pipa dengan spesifikasi API 5L X52 berukuran diameter 12" dengan ketebalan 12,4 mm dan dilakukan proses permesinan untuk mengurangi tebal menjadi 6,25 $\mathrm{mm}$.

\section{Tabel 1. Parameter Operasi Pipa}

\subsection{Pelaksanaan Eksperimen}

Penelitian ini dibagi menjadi dua langkah utama, yang pertama adalah menentukan nilai

\begin{tabular}{|l|l|l|}
\hline \multicolumn{1}{|c|}{ Parameter } & \multicolumn{1}{c|}{ Aktual } & \multicolumn{1}{c|}{ Ekperimen } \\
\hline Fluida & Gas Alam Metana & Air \\
\hline Jenis Pipa & API 5L Gr. X52 & API 5L Gr. X52 \\
\hline Tebal & $9,5 \mathrm{~mm}$ & $6,25 \mathrm{~mm}$ \\
\hline Tekanan Operasi & $1,4 \mathrm{Mpa}$ & $\begin{array}{l}\text { Pressure tidak disimulasikan } \\
\text { dalam Eksperimen }\end{array}$ \\
\hline Temperatur & $44^{\circ} \mathrm{C}$ & $35^{\circ} \mathrm{C}$ \\
\hline Kecepatan Aliran Linear & $11 \mathrm{~m} / \mathrm{s}$ & $0,07 \mathrm{~m} / \mathrm{s}$ \\
\hline
\end{tabular}

parameter pengelasan (beat input) menggunakan simulasi komputer dengan perangkat lunak PRCI (Thermal Analysis Model for Hot Tap Pengelasan V4.2). Ada 3 kelompok parameter yang disimulasikan yaitu heat input rendah; heat input tinggi dan heat input pengelasan temper bead. Hasil simulasi yang menghasilkan prediksi nilai kekerasan daerah HAZ dibawah $350 \mathrm{HV}$ dan nilai temperatur bagian dalam pipa dibawah $982^{\circ} \mathrm{C}$ akan dipilih untuk menghindari terjadinya retak hidrogen dan burnthrough. Langkah kedua adalah melakukan eksperimen pengelasan sesuai dengan standar API 1104 Annex. B, menggunakan jenis proses pengelasan Gas Tungsten Arc Welding (GTAW) dan Shield Metal Arc Welding (SMAW). Untuk proses GTAW material pengisi yang digunakan adalah ER70S-6 sesuai dengan AWS A 5.18 dengan diameter $2.4 \mathrm{~mm}$, polaritas 
listrik DCEN dengan kemurnian gas argon 99.9\%, sedangkan untuk proses $S M A W$ digunakan elektroda E7018 H4R sesuai dengan AWS A 5.5, berukuran diameter $3.2 \mathrm{~mm}$ dan polaritas listrik DCEP. Material sleeve diletakan diatas sebuah pipa utama/ header dengan posisi pengelasan $6 \mathrm{G}$ arah pengelasan naik seperti yang terlihat dalam Gambar 1.

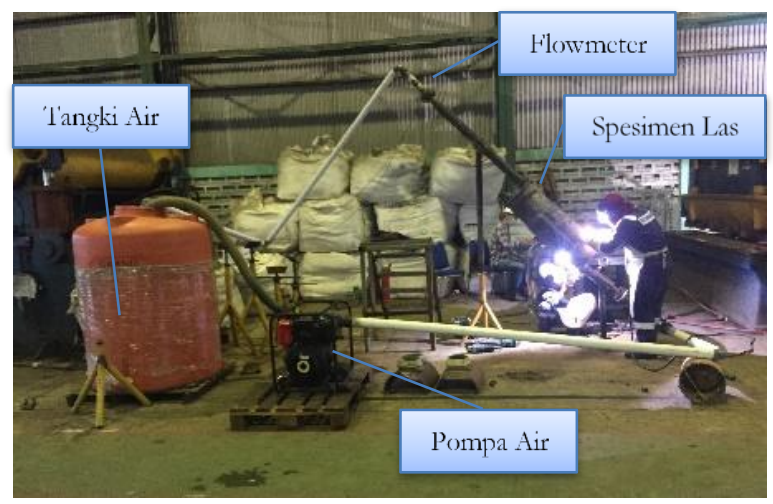

Gambar 1. Eksperimen Pengelasan

Sementara itu untuk mendapatkan nilai konveksi perpindahan panas yang sama atau lebih tinggi dengan kondisi aktual aliran air di dalam header dibuat dengan menggunakan pompa yang menghasilkan kecepatan linear $0,07 \mathrm{~m} / \mathrm{s}$ dan dipertahankan selama proses pengelasan. Urutan penempatan lasan temper bead seperti yang terlihat pada di Gambar 2.

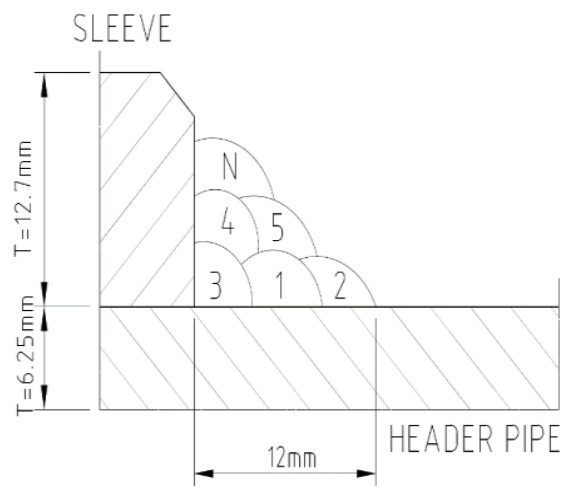

Gambar 2. Urutan Temper Bead Welding

\section{HASIL DAN PEMBAHASAN}

\subsection{Validasi Material Pengelasan}

Dari hasil validasi dengan menggunakan uji Positive Material Identification dan pengujian mekanis didapatkan bahwa material sesuai dengan persyaratan komposisi kimia dan properti mekanis API 5L Gr. X52.

\subsection{Penentuan Parameter Heat Input}

Simulasi pengelasan menggunakan perangkat lunak PRCI dengan memasukan seluruh informasi perencanaan pengelasan dan variabel heat input, dari hasil simulasi perangkat lunak PRCI disimpulkan untuk memilih perencanaan parameter dengan teknik temper bead karena 
menghasilkan suhu pipa dibawah $982^{\circ} \mathrm{C}$ dan kekerasan material pada daerah HAZ dibawah 350 HV seperti yang terlihat pada Tabel 2 .

Tabel 2. Simulasi Perangkat Lunak PRCI Heat Input Temper Bead

\begin{tabular}{|c|l|c|c|c|c|c|c|c|c|}
\hline No & Proses & $\begin{array}{c}\text { Dia. } \\
(\mathrm{mm})\end{array}$ & $\begin{array}{c}\text { Kuat } \\
\text { Arus } \\
(\mathrm{A})\end{array}$ & $\begin{array}{c}\text { Teg. } \\
(\mathrm{V})\end{array}$ & $\begin{array}{c}\text { Kec. } \\
(\mathrm{mm} / \\
\mathrm{min})\end{array}$ & $\begin{array}{c}\text { Heat } \\
\text { Input } \\
(\mathrm{kJ} / \mathrm{mm})\end{array}$ & $\begin{array}{c}\text { t8/5 } \\
(\mathrm{s})\end{array}$ & $\begin{array}{c}\text { Inside } \\
\text { Temp } \\
\left({ }^{\circ} \mathrm{C}\right)\end{array}$ & $\begin{array}{c}\text { Hardn } \\
\text { ess } \\
(\mathrm{HV})\end{array}$ \\
\hline 1 & GTAW & 2.4 & $145-159$ & $11-12$ & 78 & 1.34 & 1.88 & 431.89 & 230.68 \\
\hline 2 & GTAW & 2.4 & $145-158$ & $11-12$ & 68 & 1.58 & 2.8 & 439.3 & 210.89 \\
\hline 3 & GTAW & 2.4 & $149-158$ & $11-12$ & 77 & 1.36 & 1.89 & 433.65 & 230.3 \\
\hline 4 & GTAW & 2.4 & $162-172$ & $11-13$ & 67 & 1.82 & 2.92 & 464.72 & 209.13 \\
\hline 5 & GTAW & 2.4 & $162-168$ & $11-13$ & 70 & 1.65 & 2.42 & 458.56 & 217.58 \\
\hline 6 & SMAW & 3.2 & $120-130$ & $22-26$ & 90 & 2.00 & 5.7 & 672.81 & 187.4 \\
\hline 7 & SMAW & 3.2 & $119-130$ & $22-26$ & 111 & 3.92 & 10.7 & 665.81 & 174.95 \\
\hline 8 & SMAW & 3.2 & $120-133$ & $22-26$ & 204 & 0.89 & 2.19 & 577.7 & 222.46 \\
\hline
\end{tabular}

\subsection{Penentuan Laju Aliran Eksperimen}

Dari hasil simulasi PRCI didapatkan bahwa laju pendinginan $\mathrm{t} 8 / 5$ yang direncanakan untuk eksperimen akan lebih cepat dari kondisi aktual. Sesuai dengan Standar API 1104 bahwa laju pendinginan yang lebih cepat pada eksperimen dapat mewakili kondisi actual laju pendinginan yang lebih lambat seperti yang terlihat pada Tabel 3.

Tabel 3. Penentuan Laju Aliran Eksperimen

\begin{tabular}{|c|c|c|c|c|c|c|}
\hline Kondisi & $\begin{array}{c}\text { Diameter } \\
(\mathrm{Inch})\end{array}$ & $\begin{array}{c}\text { Tebal } \\
(\mathrm{mm})\end{array}$ & Fluida & $\begin{array}{c}\text { Laju Aliran } \\
(\mathrm{m} / \mathrm{s})\end{array}$ & $\begin{array}{c}\text { Heat Rate } \\
(\mathrm{BTU} / \mathrm{sec})\end{array}$ & $\begin{array}{c}\text { Cooling Time } \\
\mathrm{t}_{8 / 5}(\mathrm{sec})\end{array}$ \\
\hline Aktual & 12 & 12 & Metana & 11 & 3,8 & 26,9 \\
\hline Eksperimen & 12 & 6 & Air & 0,07 & 3,8 & 12,18 \\
\hline
\end{tabular}

\subsection{Hasil Pengujian Spesimen Pengelasan}

Jenis pemeriksaan dan pengujian terhadap sambungan hasil pengelasan pada proses pengelasan in-service mengacu pada standar API 1104 seperti yang terlihat pada Tabel 4 dan hasilnya sesuai dengan persyaratan yang diminta dalam standar tersebut.

Tabel 4. Hasil Uji Spesimen Pengelasan

\begin{tabular}{|c|c|c|c|c|c|c|}
\hline Tipe Las & Tensile & Nick Break & Face Bend & Root Bend & Macro \& Hardness & Micro \\
\hline Groove & 2 & 2 & 2 & 2 & - & - \\
\hline Fillet & - & 4 & 4 & - & 4 & 1 \\
\hline
\end{tabular}

Berdasarkan hasil pemeriksaan struktur makro pada sampel pipa yang telah dilas setiap lapisan pengelasan dan daerah terpengaruh panas terlihat menunjukkan logam pengisi telah bersatu dengan logam dasarnya. API 5L Grade X52 sebagai logam dasar mempunyai kemampuan menyerap panas dengan baik, sehingga HAZ yang terbentuk tidak terlalu besar. Tidak terlihat juga adanya cacat pengelasan, seperti inklusi slag, udara yang terjebak dan cacat lainnya yang dapat meningkatkan tegangan dalam seperti yang terlihat pada Gambar 3. 


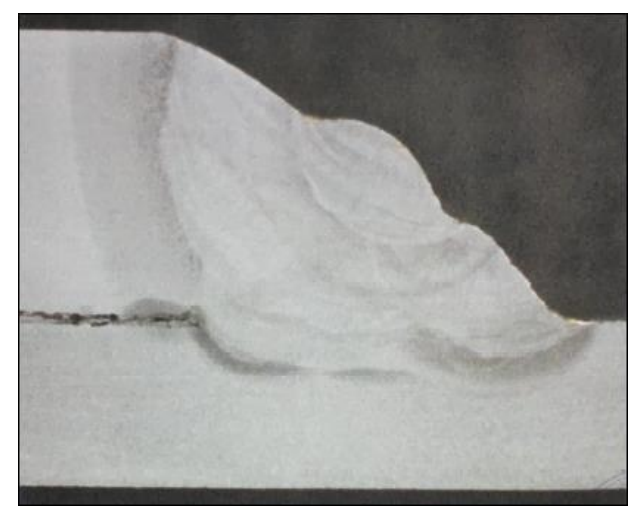

Gambar 3. Spesimen Uji Makro

\subsection{Hasil Pengujian Kekerasan}

Nilai kekerasan erat kaitannya dengan kemampuan material lasan menahan dan menyerap beban yang datang dari dalam dan luar pipa. Proses pengujiannya mengacu pada standar ASTM E92-8 dan menggunakan metode Vickers serta dilakukan pada temperatur $24^{\circ} \mathrm{C}$ pada arah jam 06.00 sebanyak 4 line/garis yang terdiri dari HAZ, logam dasar, lasan dan area Fusion Line HAZ Coarse Grain seperti yang terlihat pada Gambar 4.

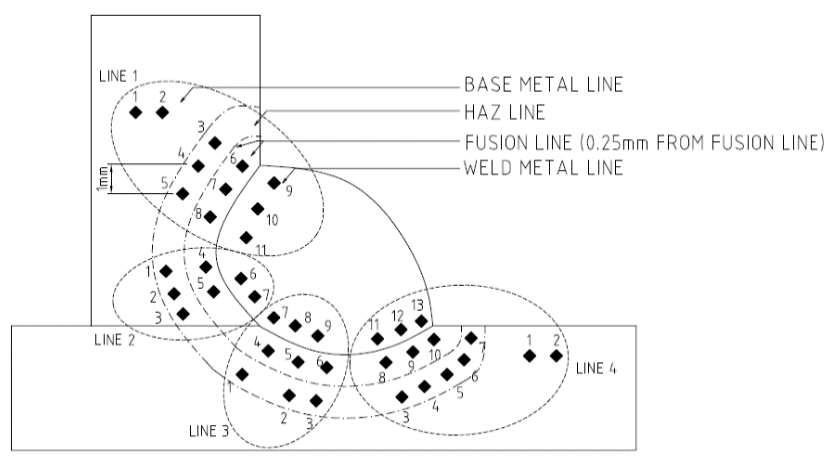

Gambar 4. Lokasi Uji Kekerasan

Seperti yang terilhat dalam Tabel 5, hasil pengujian memiliki nilai antara $181-340 \mathrm{HV}$. Nilai kekerasan bagian sleeve (line 1) lebih tinggi dari bagian header (line 2,3,4) karena proses pengelasannya menggunakan SMAW yang memiliki nilai heat input lebih besar dan tidak menerapkan metode temper bead sedangkan pada header terjadi penurunan nilai kekerasan karena penerapan metode temper bead dan penggunaan metode las GTAW yang memiliki nilai heat input lebih kecil dan juga adanya perlakuan preheat sehingga bisa mengurangi efek pendinginan cepat pada material.

Tabel 5. Nilai Uji Kekerasan

\section{Vickers $\mathrm{H}$}

ardness Value HV $5(\mathrm{kgf} / \mathrm{mm} 2)$ 


\begin{tabular}{|c|c|c|c|c|}
\hline No. & Line 1 & Line 2 & Line 3 & Line 4 \\
\hline 1 & 194 & 226 & 198 & 185 \\
\hline 2 & 196 & 220 & 201 & 181 \\
\hline 3 & 321 & 216 & 208 & 201 \\
\hline 4 & 317 & 234 & 210 & 204 \\
\hline 5 & 319 & 230 & 212 & 195 \\
\hline 6 & 335 & 225 & 215 & 198 \\
\hline 7 & 340 & 231 & 229 & 194 \\
\hline 8 & 331 & - & 237 & 196 \\
\hline 9 & 210 & - & 224 & 198 \\
\hline 10 & 216 & - & - & 202 \\
\hline 11 & 221 & - & - & 235 \\
\hline 12 & - & - & - & 238 \\
\hline 13 & - & - & - & 236 \\
\hline
\end{tabular}

Pendinginan yang lebih cepat pada proses pengelasan in-service sama halnya dengan melakukan proses quenching pada perlakuan panas sehingga menghasilkan internal stress yang tinggi dan berpengaruh terhadap nilai kekuatan dan kekerasan material pada daerah tersebut, dengan melakukan preheat akan menghasilkan perbedaan temperatur antara fluida kerja, logam dasar, dan logam cair yang relative lebih rendah jika dibandingkan jika tidak dilakukan sehingga bisa menurunkan nilai kekerasan.

Sesuai dengan persamaan Hall-Petch material dengan butir yang halus/kecil bersifat lebih keras dan kuat dibandingkan dengan material dengan butir kasar karena butir halus memiliki area batas butir total yang lebih luas untuk menghalangi pergerakan dislokasi, nilai kekerasan dan kekuatan yang lebih tinggi akan berdampak pada menurunnya keuletan dan ketangguhan dari material, hal ini dapat terlihat pada nilai kekerasan daerah HAZ coarse grain $(0,25 \mathrm{~mm}$ dari Fusion Line) yang lebih tinggi dibandingkan daerah Base Metal. Selama proses pengelasan daerah las dan HAZ akan mengalami serangkaian siklus termal pemanasan sampai mencapai suhu fusi las dan kemudian diikuti dengan pendinginan cepat sebagai akibat fluida yang mengalir dalam pipa, hal ini mempengaruhi struktur mikro dan sifat mekanik daerah logam las dan HAZ.

Pengelasan dengan metode temper bead menyebabkan logam las dan daerah terpengaruh panas yang ada di bawahnya akan mengalami pemanasan berulang (reheating). Selama proses reheating logam las mengalami pemanasan hingga temperatur austenit yang dapat melarutkan berbagai paduan yang terdapat dalam baja. Oleh karenanya heat input yang diberikan selama pengelasan menjadi sangat penting karena dapat menjadi faktor prediksi mikro stuktur akhir yang akan terbentuk. Heat input yang semakin besar akan menghasilkan temperatur puncak yang semakin tinggi dan gradien temperature terhadap waktu pendinginan yang semakin besar. Gradien yang semakin besar menunjukkan laju pendinginan pasca pengelasan semakin tinggi. 


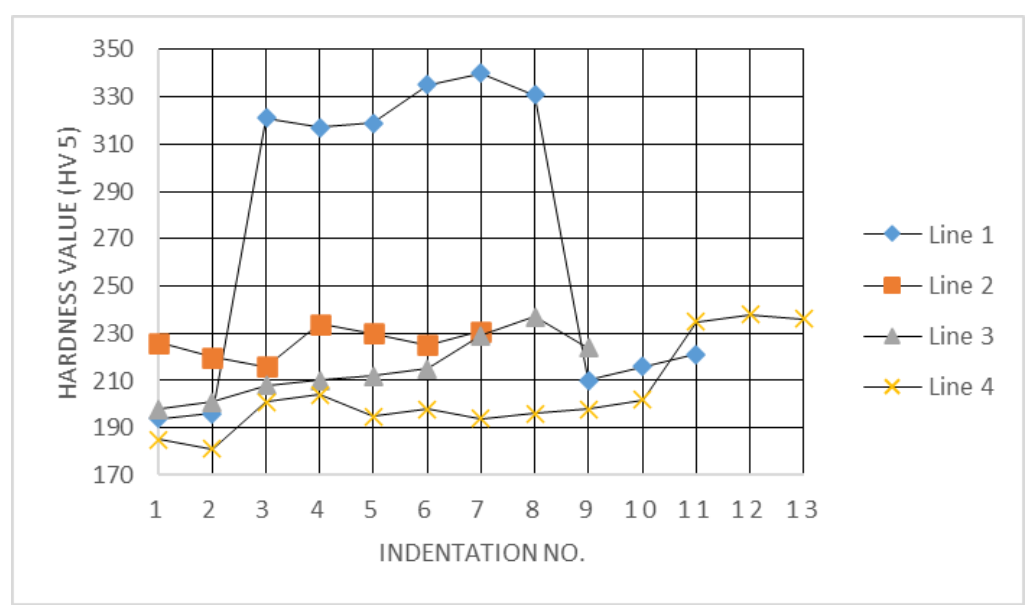

Gambar 5. Grafik Kekerasan Material

Pengelasan Temper bead yang dilakukan menyebabkan terjadinya pendinginan yang tidak kontinyu tetapi efek pendinginan fluida didalam pipa berlangsung secara terus menerus. Selama pengelasan, daerah las akan mengalami pendinginan dari suhu yang lebih tinggi hingga mencapai temperatur interpass dan kemudian akan mengalami pemanasan kembali oleh lapisan selanjutnya, kondisi ini akan menyebabkan terjadinya struktur mikro dengan karakteristik masing-masing sesuai karakter transformasinya.

\subsection{Hasil Pengamatan Struktur Mikro}

Siklus pendinginan pada proses pengelasan pada umumnya berlangsung secara kontinu tanpa adanya penurunan suhu secara mendadak sedangkan pada proses pengelasan in-service pendinginan berlangsung cepat sehingga untuk menganalisa struktur mikro hasil pengelasan tidak dapat menggunakan diagram fasa yang hanya dapat dipergunakan pada laju pendinginan lambat dan terjadi proses difusi atom, karena itu untuk menganalisis struktur mikro hasil pengelasan in-service digunakan diagram Continuous Cooling Transformation (CCT).

Pada proses pengelasan, transformasi fasa ferit $(\alpha-\mathrm{Fe})$ dan austenit $(\gamma$-Fe) merupakan tahap yang paling krusial karena struktur mikro logam las yang berarti juga sifat-sifat mekanisnya sangat ditentukan pada tahap ini. Diantara faktor-faktor yang mempengaruhi transformasi $\gamma$ (austenit) ke $\alpha$ (ferit) adalah heat input, komposisi kimia las, kecepatan pendinginan dan bentuk sambungan lasan.

Pengamatan struktur mikro pada daerah material induk, area lasan dan area HAZ dilakukan dengan pembesaran foto 500x yang diambil pada area header dimana dilakukan pengelasan kombinasi GTAW dan SMAW dan adanya pendinginan cepat oleh fluida.

Hasil pengamatan pada daerah lasan bisa dilihat pada Gambar 6. Struktur yang tampak adalah perlit dan ferit, dimana perlit berwarna gelap dan ferit berwarna putih lebih mondominasi. Ferit yang mempunyai sifat lunak lebih banyak mendominasi struktur baja dan perlit mempunyai sifat yang lebih keras berada diantaranya dengan jumlah yang lebih sedikit mempunyai posisi yang tidak teratur.

Hasil pengamatan pada daerah HAZ dapat dilihat pada Gambar 7. Struktur mikro didominisi oleh acicular ferit-perlit. Pada daerah HAZ yang dekat pada garis lebur akan terjadi pembentukan ferit dengan cepat pada saat proses pengelasan berlangsung sehingga struktur berubah sesuai dengan siklus thermal yang terjadi sehingga menyebabkan daerah HAZ terjadi penurunan kekuatan yang mengakibatkan menjadi daeah yang rawan getas. 
Hasil pengamatan pada daerah Base Metal seperti pada Gambar 8. Struktur mikro masih didominasi oleh ferit-perlite. Pada daerah induk struktur ferit mengalami pertumbuhan sedikit saat proses pengelasan berlangsung karena mendapat panas sehingga struktur berubah sesuai dengan panas yang didapat dari pengelasan.

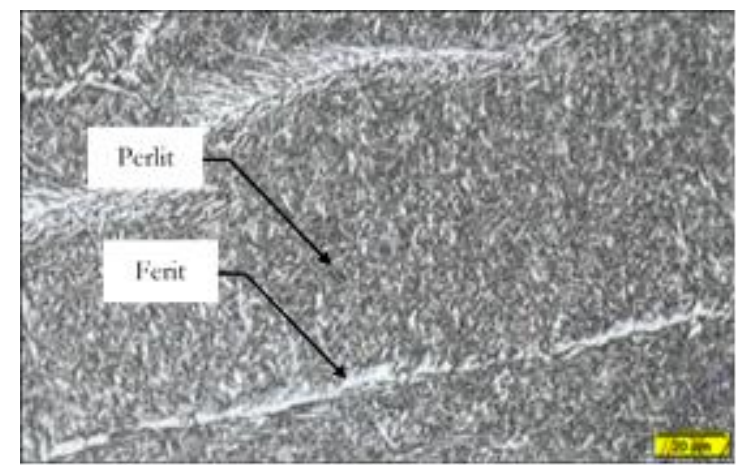

Gambar 6. Struktur mikro pada daerah Logam Las

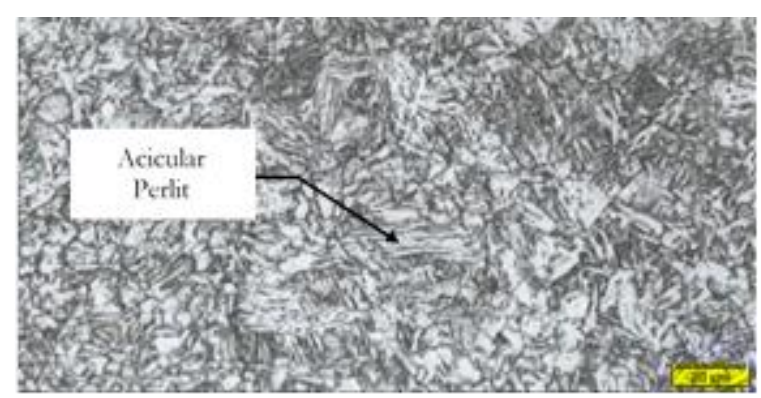

Gambar 7. Struktur Mikro pada daerah HAZ

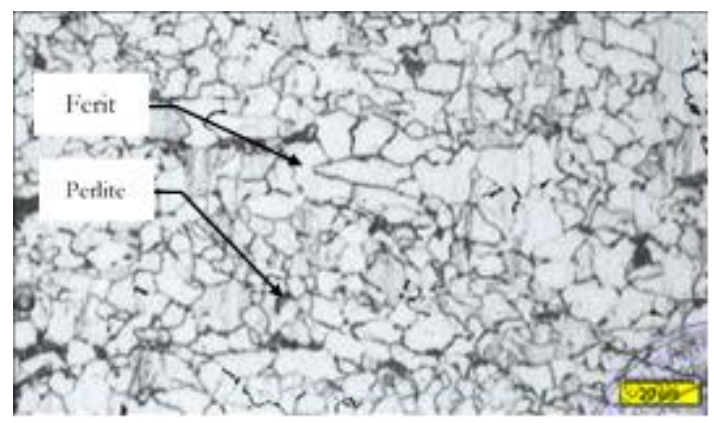

Gambar 8. Struktur Mikro pada daerah Base Metal

\section{KESIMPULAN}

Pengelasan kombinasi GTAW dan SMAW dengan metode temper bead dan penerapan preheat pada pengelasan in-service dapat menurunkan nilai kekerasan di HAZ dan resiko terjadinya burnthrough dapat dihindari sehingga dapat dipergunakan dengan aman pada proses pengelasan hot tapping pipa penyalur Gas Alam tanpa perlu melakukan penurunan parameter operasi pipa penyalur seperti penurunan tekanan dan laju aliran, sehingga tidak menimbulkan kerugian lingkungan dan sosial ekonomi. 


\section{DAFTAR PUSTAKA}

API (2018), API specification 5L Specification for line pipe. Washington, D.C.: American Petroleum Institute.

ASME. (2019). Section II Materials Part C Specifications for Welding Rods, Electrodes, and Filler Metals Material. American Society of Mechanical Engineers.

ASME. (2019). Section V Non Destructive Examination. American Society of Mechanical Engineers.

ASTM (2015). E340-15, Standard Practice for Macroetching Metals and Alloys, ASTM International, West Conshohocken, PA. www.astm.org.

Boran, J. The Hot-Tapping of Sub Sea Pipelines. Welding Review, vol6, no 4 Nov 1987, pp283284

Bruce, William. (2002). Qualification of Procedures for Welding Onto inservice Pipelines.

Cassie B. A., (1974) The Welding of Hot Tap Connections to High Pressure Gas Pipelines, Pipeline Industries Guild J. W. Jones Memorial Lecture.

Callister Jr, W. D., \& Rethwisch, D. G. (2012). Fundamentals of materials science and engineering: an integrated approach: John Wiley \& Sons.

Cheng, Wentao \& Wang, Yong-Yi \& Amend, William \& Swatzel, Jim. (2004). Weld Microstructure and Hardness Prediction for inservice Hot-Tap Welds. Proceedings Biennial International Pipeline Conference.

Cola M. J. \& Threadgill P. L., (1988) Final Report on Criteria for Hot Tap Welding, American Gas Association, Edison Welding Institute Project J7038.

D.Nolan,Z. Sterjovski and D.Dunne.,Modelling of HAZ Hardness in C-Mn Pipeline Steels Subjected to In-Service Welding Procedures. IIW Document No.IX-2165-05.

Farzadi, Ali. (2015). Gas Pipeline Failure Caused by In-Service Welding. Journal of Pressure Vessel Technology.

Huang, Zhiqiang \& Haiping, Tang \& Ding, Yaping \& Wei, Qinwen \& Xia, Guofa. (2017). Numerical Simulations of temperature for the in-service welding of gas pipeline. Journal of Materials Processing Technology.

Kwankaew, Supolchai \& Phaoniam, Rittichai \& Poopat, Bovornchok \& Srisutraporn, Sermsak. (2018). Inservice Operating Conditions Affecting On Weld HAZ Hardness For API5L Gr.B Pipe Steel Maintenance.MATEC Web of Conferences.

Qian, Wu \& Yong, Wang \& Tao, Han \& Hongtao, Wang \& Shiwei, Gu \& Laihui, Han. (2019). Study on the Failure Mechanism of Burn-Through During In-Service Welding on Gas Pipelines. Journal of Pressure Vessel Technology.

Sperko, W.J.. (2005). Exploring Temper Bead Welding. Welding Journal (Miami, Flo). 84. 37-40.

Srisutraporn, Sermsak \& Phaoniam, Rittichai \& Poopat, Bovomchok \& Kwankaew, Supolchai. (2018). Effect Of Tempered Bead Techniques On Maximum HAZ Hardness For In Service Pipeline Welding. MATEC Web of Conferences.

Trench, C. J., \& Kiefner, J. F. (2001). Oil Pipeline Characteristics and Risk Factors: Illustrations from the Decade of Construction.

Tawancy, H., Al-Hadhrami, L. M., \& Al-Yousef, F. (2013). Analysis of corroded elbow section of carbon steel piping system of an oil-gas separator vessel. Case Studies in Engineering Failure Analysis, 1(1), 6-14.

Wade J.B., (1978) Effect of Preheat on Hot Tapping Procedures, Australian Welding Research Association Research Report, Snowy Mountains Corporation.Wade J.B., (1978) Effect of Preheat on Hot Tapping Procedures, Australian Welding Research Association Research Report, Snowy Mountains Corporation. 